\title{
Audit Fee Determinants and Audit Quality in Ethiopian Commercial Banks
}

\author{
Tamrat Afesha
}

\begin{abstract}
The audit profession has been highly scrutinized among researchers and regulators following the fall of giant companies in the west. One of the issues that gained momentum has been to analyze the audit fee structure and the various auditor-client relationships. This study investigates the determinants of audit fees and the ex-ante audit quality based on variables unique to the banking firms and considered important by regulators in Ethiopian commercial banks. The study also examined whether auditors value factors considered important by the regulatory bank, which result in better alignment of interests of auditors and regulators. The study used panel data for eight commercial banks from the year 2004-2012. The panel fixed effect regression result revealed bank size, liquidity, efficiency, loan growth, capital adequacy and auditor size are significant determinants of audit fees in Ethiopian commercial banks. However, among the factors considered important by the regulatory bank, credit risk is found to be insignificant. With regard to audit quality, the study did not find significant relationship between the extent of earning management and abnormal audit fees, indicating that auditors do not seem to compromise audit quality to secure abnormally higher audit fees. The researcher recommends auditors to further align audit fee valuation with the interests of regulatory bank, particularly in respect of credit risk.
\end{abstract}

Keywords: audit fees, regulatory risks, audit quality, earning management, Loan Loss Provision.

http://dx.doi.org/10.4314/ejbe.v5i2.1

*Jigjiga University, Jigjiga, Ethiopia, Email: tamratfsh@ gmail.com, Mob.: 251913372042 
Audit Fee Determinants and Audit Quality

\section{Introduction}

The pricing of audit services has been an interesting topic for audit researchers, and plenty of audit studies were conducted to investigate factors believed to have an influence on audit fees in industrial companies. This line of research has been intensified following the fall of high profile giant companies at the down of the century in the west (Enron, WorldCom). The incident raised significant criticism on the auditing profession as a whole, for the fact that auditors were implicated in many of the cases. It was revealed that auditors drive higher non-audit fees and abnormally higher audit fees, which motivate them to lose their independence (Dart 2009, Ghosh, et al. 2006). The banking crisis which started in 2007 also reignited a similar concern on the auditing profession. It has been exposed that many banks lacked transparency and reported profits that were based on under-secured and rather reckless lending (Deloitte, 2012). Emergent economies are not exceptional from large corporate failures; for instance the corporate failures in the Nigerian financial sector in the early 1990s brought auditors into sharp focus and caused the public to question the role of accountants and auditors (Akinpelu et al 2013).

Unlike other industries, banking firms are characterized by the different nature of their operation and greater scrutiny from regulatory bodies. Audit fee researchers (Simunic 1980 and Fields et al. 2004) suggest that audit fees for every company should be a function of client size, business complexities and client business risk. However, the audit fees studies for banking firms left unexamined for two key reasons: first, most of the measurement variables for risk and complexities used in other industries are not suitable for banks. Secondly, the presence of vigilant regulation places a countervailing effect in the audit service, it may induce auditors to plan their audit in less intensive manner and charge lower audit fees (moral hazard), at the same time, it also places a higher litigation risk on the auditor because both regulators and owners may bring court action in case of audit failure (Fields et al. 2004; Boo and Sharma 2008). As Fields et al (2004) argued, to avoid such a costly litigation, bank auditors should consider factors that are most important to regulators in pricing their audit service to better align with the interest of regulators. In this regard, it is evident that most countries of the World, bank regulators use CAMELS (Capital adequacy, Asset quality, and management efficiency, Earning Quality, Liquidity and Sensitivity to market) for their offsite surveillance mechanism including Ethiopia

In view of these basic differences in banks operation and operating environment, most audit fee studies exclude banking firms (Simunic 1980; Palmrose 1986; Francis and Simon 1987, Gerrard, et al. 1994;Thinggaard and Kiertzner 2008 and Caneghem 2010). While, few recent studies model bank 
audit fees in terms of factors considered important to regulatory bodies and find interesting results (fields et al. 2004; Boo and Sharma 2008; Lobo et al. 2010; Ettredge et al. 2011; Schneider and Tran 2013; Akinpelu et al. 2013).

The traditional audit fee studies have also been extended to examine the economic bond between auditor and the client company and the resultant effect on audit quality. This strand of research has come up with inconclusive results. While most of the studies find evidence supporting that Non Audit Service (here after NAS) and abnormally higher audit fees indeed reduce the audit quality putting auditors in a compromising position which threatens their independence (DeAngelo 1981; Choi, et al. 2010). Few studies also argue that NAS and abnormally higher audit fees are associated with improved audit quality (Davis, et.al, 1993; Defond, 2002). Although various proxies are available, the audit quality measure commonly used in the audit literature is abnormal accruals, estimated based on Jones accrual model (Beattie 2012). While, Loan Loss Provisions (LLPs) are used in banking firms. In this regard several researchers agree that LLPs are the largest and most important accruals for banks (Lobo et al. 2004).

The Ethiopian audit market environment has unique features unlike other countries. Among others the major difference lies in its market structure; stiff competition; absence of international Big auditors; weak professional body and consistent rules applicable in discharging professional responsibilities (World Bank 2007). This feature of the audit market is likely to raise many concerns on the external audit practice in the country. It is indicated that the thin audit market and the stiff competition (partly triggered by the bidding system) among audit firms lowered the audit fees in the country (World Bank 2007 and Mihret 2011).

Audit fee is a complex issue (Simunic, 1980) and connected to auditor independence and quality concerns. Economic theory indicates, when an auditor derives a high proportion of revenue from a particular client creates economic bonds on the auditor and causes the auditor to be financially reliant on the client, which can cause the auditor to lose objectivity (DeAngelo 1981). It was reported that a series of accounting scandals in the West were associated with higher audit and non-audit fees. In an effort to resolve this complex issue regulators, researchers and professional bodies have given much emphasis and a lot of audit fee studies have been conducted.

However, it is unfortunate that no single study has been conducted to the best of the researcher's knowledge, in audit fees and audit quality in the giant Ethiopian banking industry. Let alone Ethiopia, which had problematic accounting and auditing practices, countries with advanced practices couldn't stop their high profile companies from falling. Moreover, taking into account 
the significance of banks to the economy, their financial transparency has a paramount importance to various stakeholders. Therefore, given such a unique audit environment characterized by stiff competition, regulatory laxities in the accounting profession, and lower audit quality concern afforded in the country, it is imperative to investigate the audit fees and its implication on the audit quality in the Ethiopian commercial banks context.

Therefore, this study intends to determine whether the determinant factors identified in prior bank audit fee studies holds for Ethiopian commercial banking sector as well. The study also investigates whether the economic bond between the auditor and bank clients leads to a reduced audit quality by compromising auditor independence, using abnormal audit fees and level of earning management as proxies. This article is organized in four sections. The first section discusses the issues related to audit fees, audit quality, auditor independence and earning management in banking firms and the hypothesis for the study. The second section deals with research design which includes model and variable description and data. The third section is dedicated to the results and discussion of results while the last section presents summary of results and recommendations.

\section{Literature Review}

\subsection{Audit Fee, audit quality and auditor independence}

The Securities and Exchange Commission (SEC) defined audit fee as the fees paid for annual audits and reviews of financial statements for the most recent fiscal year. Chersan et al. (2012) also defined audit fee as the sums payable/paid to the auditor, for the audit services offered to the auditee. Meanwhile, according to the rules of ethics of public accountant's compartment, the fee amount may vary depending on the risk assessment, the complexity of services provided, level of expertise required to perform such services, the related cost structure of the CPA firm and other professional considerations. In this regard, Code of Ethics for Professional Accountants (IFAC, 2010) provides that "when entering into negotiations regarding professional services, a professional accountant in public practice may quote whatever fee is deemed appropriate" (Section 240).

However, virtually all professional ethics for accountants i.e. (OFAG 2009), (AICPA, 2009) and (IFAC, 2010) remind the threats that may arise with regard to the fundamental ethical standards i.e. independence, objectivity and professionalism, when different levels of fee levels are billed. It should be noted that if an auditor charges a lower fee than another auditor, this is not unethical, if the audit is carried out at an analogous quality level. 
Audit pricing is a complex issue that takes into account various client and auditor attributes DeAngelo (1981). Like the suppliers of other professional services auditors take into account both the cost and quality of the audit when pricing their services. Consistent with this view, Simunic (1980) was the first to develop an extensive model of audit fees. In examining the competitiveness of the audit market, he hypothesized and found factors relating to auditee size, auditee complexity, auditee asset composition, auditee industry, auditee risk and financial distress, auditor's tenure and auditor type (Big 8/6/5 vs. non-Big $8 / 6 / 5)$ to be associated with audit fees.

Audit fee researchers (Simunic 1980 and Fields et al. 2004) suggest that audit fees for every company should be a function of client size, business complexities and client business risk. However, unlike other industries, banking firms are characterized by the different nature of their operation and greater scrutiny from regulatory bodies. First, most of the measurement variables for risk and complexities used in other industries are not suitable for banks. For example, leverage and quick/current ratio measures used in other industries cannot properly capture the risk and complexities involved with banking firms. Secondly, the presence of vigilant regulation cast its effect in the audit service in either of the two ways. On the one hand, tight regulation of banks may induce auditors to plan their audit in less intensive manner and charge lower audit fees (Boo and Sharma 2008). On the other hand, it also places a higher litigation risk on the auditor because both regulators and owners may bring court action in case of audit failure (Fields et al. 2004; Boo and Sharma 2008).

To avoid such a costly litigation, it is argued that bank auditors should take into account factors that are most important to regulators in their audit fee determination to better align with the interest of regulators (Fields et al 2004). It is known that most countries of the world, be it developing or developed, bank regulators use CAMELS (Capital adequacy, Asset quality, management efficiency, Earning Quality, Liquidity and Sensitivity to market) for their offsite surveillance mechanism including Ethiopia. In light of this, bank audit fee studies model audit fees around these CAMELS ratios (Fields et al 2004; Lobo et al. 2010; Ettredge et al. 2011).

\subsection{Audit quality and independence}

DeAngelo (1981) defined audit quality as the market-assessed joint probability that an auditor will discover an error in the client's account and report the error to the third parties. She also suggested the probability that a given auditor will discover a breach depends on the auditor's technological capabilities, the audit procedures employed on a given audit, the extent of sampling, etc. Further, the 
conditional probability of reporting a discovered breach is a measure of an auditor's independence from a given client.

Several factors have been identified in the literature which may influence auditor's independence such as lack of stricter regulations, the nature of the auditor-client relationship, extended audit tenure, the provision of NAS, competitive pressures leading to lowballing /price cutting. Economic dependence (proportion NAS to total audit fees) of external auditors has received researchers attention. It is argued that provision of NAS by incumbent auditors impair auditor independence. First, NAS fees make auditors to be financially dependent on their client, and as a result weaken to resist management pressure for fear of losing their business. Secondly, the consultancy nature of NAS puts auditors in a compromising position which potentially threatens their independence about the transaction they audit. In addition, Positive abnormal audit fees or the presence of positive client specific quasi rent creates an incentive for the auditor to compromise independence with respect to a specific client (DeAngelo 1981; Choi, et al. 2010; DeFond et al. 2002)

However, a counter theoretical argument also suggests that auditors have market-based institutional incentives to act independently. The expected costs of sacrificed independence include the reputation loss and litigation costs associated with audit failures Defond (2002). The size of the audit firm is often considered when examining the issue of fee dependence. For example, DeAngelo's (1981) economic model states that incentives for an auditor to compromise independence will be a balance between the importance of the client and the litigation and reputation costs which could result from breached auditor independence. She further argues that smaller accounting firms may have bigger incentives to compromise independence than larger accounting firms as smaller firms have fewer clients and so each client represents a larger proportion of income to the auditor.

Ahmad et.al, (2006) suggested positive and negative abnormal fees create different incentive effects. For clients with positive abnormal fees, auditors are more likely accept client pressure as abnormal audit fees increase, whereas for clients with negative abnormal fees, auditors are unlikely to compromise audit quality. Regarding the relationship between audit fees and Non audit fees, (Simunic (1984), cited in Ahmed et, al (2006)) argues that negative relationship among audit fees and Non audit fees is due to the knowledge spill over from the provision NAS to audit. In other words, the knowledge gained through the provision of NAS can be utilized in the audit. The client would benefit from the knowledge spillover in the form of lower audit fee. 
Audit Fee Determinants and Audit Quality

Apart from level of NAS and audit fees, auditor size has been the most commonly used quality surrogate and it has been employed in a vast body of prior audit research. DeAngelo (1981) analytically shows that auditor likelihood of reporting breaches (i.e. independence) increases with audit firm size. Thus, according to the DeAngelo's framework, audit quality is a function of the (market-assessed) competence and independence of the auditor. She proposes that the auditor's investments (start-up costs) in the client relationships enable the incumbent auditor to earn client-specific quasi-rents and that these quasi-rents represent the collateral that is lost if 'promises' are not kept (i.e. in case of audit failure). According to this framework, auditors with a larger number of clients possess greater total collateral and as a consequence of avoiding audit failure arguably report a more independent opinion on client's accounts (DeAngelo 1981).

\subsection{Loan loss provision and earning management}

Banks use loan loss provisions to create reserves in order to cover the expected (latent, inherent or incurred and not yet individually identified) losses embedded in their loan portfolios. In principle, LLPs must be used to cover expected losses; however in practice due to bank managers discretion in estimating this item, provisioning policy can become an important tool to pursue goals that are different from a fair representation of the expected evolution of a bank's loan losses (Pérez et al. 2006; Curcio and Hasan 2008).

Earnings management implies the manipulation of reported earnings in such a way that the bottom line of the profit and loss account does not represent the real economic result of a bank's activity. Various studies find evidence that bank managers use the discretionary component of LLP as a tool for earning management (Anandarajan et al 2005; Curcio and Hasan 2008; Pérez et al 2006; Biase and D'Apolito 2012; Lobo et al. 2004). As (Lobo et al. 2004) suggested, bank LLP is well-suited to studying earnings management for the following reasons. First, Bank managers have considerable discretion in estimating LLP. This discretion allows them flexibility in using LLP for income-increasing or income-decreasing earnings management, or for smoothing earnings. Second, LLP is also by far the largest and most important accrual for banks, thus affording bank managers wide latitude in its use.

Several bank earning management studies (see Walter 1991;Anandarajan, et al. 2005; Pérez et al. 2006; Curcio and Hasan 2008: Balla et al. 2012) provide the central incentives (reasons) to use LLP as a management tool. Capital regulation, income smoothing, signaling and taxes are the most underscored reasons for banks to engage in earning management through LLP. Besides, Walter (1991) noted the desire to limit the expenses of estimating future loan 
losses continues to provide an incentive for banks to hold reserves at levels that differ from their best estimates of the losses inherent in their loan portfolios.

Pérez et al. (2006) indicated income smoothing as one of the primary objectives of earnings management which aimed at reducing the variability of net profits over time. During good years managers use some discretionary items in the profit and loss account in order to decrease the amount of profits. During bad times, those funds can be used to prop up the bottom line. Several reasons could be forwarded for banks to engage in income smoothing. From the risk perspective income smoothing implies less volatile earnings and this reduced volatility is assumed to convey a signal of lower risk (Anandarajan, et al. 2005). Income smoothing also helps banks to maintain higher stock prices, and helps bank managers meet their compensation targets (Balla et al. 2012). Further as (Pérez et al. 2006; Curcio and Hasan 2008) suggested, banks are subject to minimum capital requirements and income smoothing can be the result of accounting practices aimed at meeting these requirements. Balla et al. (2012) from a prudential perspective, income smoothing could reduce the negative impact of asset volatility on bank capital. Further, Curcio and Hasan (2008) conjectured Capital management through loan-loss provisions based on the idea that bank managers use provisions to avoid the costs associated with the violation of capital adequacy requirements.

\section{Hypothesis}

Bank size: it is generally assumed that as the audit client/Auditee size increases the audit fee that the audit firm charge will also increase. This positive relationship has been justified on the ground that firms with large size require more audit hours to analyze large volume of transactions, subsidiaries, various classes of assets (Simunic 1980; O'Keefe, et al. 1994; Caneghem, 2010; Gonthier-Besacier and Schatt, 2007). Hence the longer the audit hours the higher would be the audit fees. The relationship between client size and audit fee is empirically evidenced across countries and conventionally all the studies found positive relationship (e.g. Simunic 1980; O'Keefe, et al., 1994; Ahmad et al., 2006; Naser, et al. 2007; Al-Harshani 2008; Caneghem, 2010; El-Gammal 2012). Bank audit literature demonstrates the same effect of bank size. As Cullen et al. (2012) indicate that the client size by itself (proxied by the natural logarithm of total assets) explains over $70 \%$ variances in audit fees. In addition, bank size is highly correlated with a series of bank financial risk measures, asset securitization risk measures and auditor attributes suggesting the effect of bank size could be either direct or via its indirect effects on other audit fee determinants(Ettredge et al. 2011). Based on the above theoretical argument a positive relationship between audit fees and bank size will be 
expected. Similar to prior studies a natural logarithm of total asset is employed for the fact that the relationship may not be linear.

H1: Bank size has a positive relationship with audit fees.

Audit firms Size: DeAnglo (1981) analytically demonstrated that larger audit firms provide a better quality audit than their smaller counterparties. However, the empirical evidence shows mixed result whether larger audit firms charge a higher audit fee premium for the quality service they provide than the smaller ones. Palmrose (1986), Francis and Simon (1987) found a positive relationship between audit fee and auditor size. In this study a positive relationship between audit fees and the auditor size is expected. The study used the auditor grade given by OFAG to classify auditor's size into Big Versus non-Big. .

H2: Auditor size has a positive relationship with audit fees.

Client profitability: Client profitability reflects the extent to which an auditor may be exposed to a loss in the event a client is not financially viable and eventually fails (Simunic, 1980). Poor profitability and high level of variability in profits may lead to greater risk and greater amount of audit work. Companies that report losses in the recent period's financial statement may influence the auditor's judgment of risk. The poorer the performance of the firm, the higher the risk for the auditor and the higher audit fee would be expected. On the other hand, some researchers argued profitable firms have more transactions related to the income and expense accounts thus the auditor need more time and effort to inspect those accounts, leading to a higher audit fee (Naser et al. 2007). Studies use various measures for profitability for example; (Simunic 1980; Ireland and Lennox 2002; Caneghem 2010) used recent period loss and find significant relationships. Others e.g. (Ebrahim 2010) using ROA reported profitability significantly influence audit fee. In this study only ROA is used to measure banks profitability for the fact that the client banks do not report loss during the study period. In this study, a direct relationship between banks profitability (measured through ROA) and audit fees expected.

H3: Banks profitability has a positive relationship with audit fees.

Liquidity risk: Liquidity risk relates to the possibility that the bank cannot meet its obligations for cash through the clearing system or from its depositors. Transactions accounts arise from the basic banking function of providing a means of payment to consumers and businesses. Fields et al., (2004) noted that banks with large numbers of transactions accounts necessarily have much more complex activities that are costly to perform and monitor. Moreover, large numbers of transactions accounts are usually associated with a significant number of ATM machines and a large inventory of currency and coin, which are also costly to maintain and monitor. They argued banks with higher 
Audit Fee Determinants and Audit Quality

transactions accounts have higher liquidity risk and greater operational complexity. Therefore, these banks should have higher audit fees. However, Ettredge et al. (2011) argued large numbers of transactions accounts increases operational complexity but not liquidity since the cash balances must be available to serve account customers rather than to pay creditors. Therefore, it's not clear whether the increased audit fee is associated with liquidity risk or the complexity which arise out of maintaining large numbers of transactions accounts.

As (Fields et al., 2004) noted, liquidity risk is decreasing in the proportion of total assets held as securities, banks holding more securities should have lower audit fees. They also suggested, fees may also be negatively related to investment securities because the relative transparency of the asset portfolio should make the associated audit work less complicated. Prior researchers used liquidity proxies like demand to total deposits and investment in securities (Fields et al 2004, Ettredge et al 2011, and Lobo et al 2010). Schneider and Tran (2013) measured liquidity risk as the relationship between liabilities with a maturity of less than one year to those with a maturity of more than one year. In this study liquidity is proxied by demand deposits to total deposits and liquid assets to total assets. Based on the above arguments liquidity risk is expected to have a positive relationship with audit fees in this study.

H4. Liquidity risk has positive relationship with audit fees.

Credit risk: Credit risk primarily involves the quality of the bank's assets and the probabilities of default in its loan portfolio, though credit risk may also exist in the securities portfolio. Boo and Sharma (2008) contended bank auditors need to review the credit quality of borrowers and assess the effectiveness of the bank's credit risk management practices. Credit risk is measured by the quality of banks asset and loan portfolio composition. Nonperforming loans and loan charge-off rates are the primary indicators of the bank's asset quality. Non-performing loans imply greater risk as the likelihood of default is higher compared to performing loans. Increasing levels of non-performing loans is expected to demand greater audit effort.

In addition to the Asset quality measures, the loan composition also presents different risk exposure because some types of loans are more risky than the others. In this regard, as Fields et al. (2004) suggested, in contrast to noncommercial loans, commercial loans are complex transactions and frequently involve significant collateralization. Furthermore, the audit and evaluation of a commercial loan portfolio is difficult because the portfolio lacks transparency, thereby increasing measuring and monitoring costs. Even though, residential and mortgage loans have a very lower default rate the growth of securitization in such loans increase the associated audit work and audit fees increase 
accordingly. Here, in Ethiopian context loan securitization is not practical and therefore mortgage and real-estate loans may have lower default rate in contrast to Commercial loans. In this study, the definition for commercial loans includes trades (both domestic and international), service and industrial loans. Many studies found positive association between audit fees and bank credit risks (Fields et al. 2004; Ettredge et al. 2011; Lobo et al; 2010; Doogar et al. 2012; Cullen et al. 2012; Schneider and Tran 2013). Likewise, in this study a positive relationship between audit fee and the credit risk proxies (Nonperforming loan rates, net loan charge offs and commercial loans) is expected. H5: Banks Credit risk has positive relationship with audit fees.

Operating risk: Operating risk refers to the possibility of high operating costs depleting the capital account of the bank. Banks with high operating risk will find it difficult or impossible to earn acceptable profit without taking unacceptable risk. Higher ratios lead to reduced profitability, making it more difficult for banks to increase equity (retained earnings) and regulatory capital. High (inverse) efficiency ratios often reflect non-interest expenses arising from large numbers of transactions accounts and geographically dispersed branch systems (Fields et al. 2004; Ettredge et al. 2011). Further, Ettredge et al. (2011),suggested Management deficiency can attract fraud and errors in management and operations leading to higher audit risk. He further, contended, earnings ratios are one of the important signals in going concern consideration; unfavorable earnings performance are also regarded as an incentive to manipulated reporting. Therefore, based on the above arguments audit fees are expected to have a positive relationship with operating risk. Similar to prior studies in bank audit literature, total operating expense to total revenue is used as a proxy for efficiency.

H6: Banks operating risk have a positive relationship with audit fees.

Capital risk: Capital risk refers to the potential that shrinkage in the value of assets will deplete the bank's equity account. Bank capital serves to absorb losses, promote public confidence; helps to restrict excessive asset growth and provide protection to depositors (Ettredge et al. 2011). Theoretically, audit fees should be increasing in the client's level of capital risk. However, as (Fields et al. 2004; Doogar et al. 2012; Schneider and Tran 2013) suggested the relationship between audit fees and the risk-adjusted capital ratio could conceivably be positive or negative. Practically speaking, riskier banks are often required by regulators to maintain larger regulatory capital cushions. In this sense, higher capital ratios might imply worse risk status and higher specifically-set minimum capital requirements. Accordingly, in such situations a positive relationship would be expected between the risk-adjusted capital ratio and audit fees. Further, Doogar et al (2009) suggested that a higher capital 
ratio may often counter-intuitively indicate bank riskiness since it reduces return on equity, a key performance metric. Ettredge et al. (2011) also contended that the evaluation of capital adequacy should also consider other aspects of financial risks, including management capability, asset quality and composition, Earnings, growth prospect and contingent liabilities. For example, problematic asset quality implies potential expected losses and a weakened capital position at a future point of time a bank's earnings performance may have impact on the present and expected capitalization level; and serious contingent liabilities may lead to capital depletion. Prior researchers employed different measures for capital adequacy i.e. total riskadjusted capital ratio and intangible assets (Fields et al. 2004; Ettredge et al. 2011; Schneider and Tran 2013).While Cullen et al. (2012) employed riskadjusted capital ratio. In this study a negative relationship between audit fee and capital risk is expected. As a measure of capital adequacy, risk-adjusted capital ratio is employed in this study.

H7: Banks capital risk has Positiverelationship with audit fees.

Audit quality: The existence of (excess/positive) client-specific quasi-rents creates an incentive for the auditor to compromise independence with respect to a specific client (DeAngelo 1981; DeFond et al. 2002). As Choi et al. (2010) conjectured when the auditor receives abnormally high audit fees from a client (i.e., abnormal audit fees are Positive), the auditor possibly allow the client to engage in opportunistic earnings management. He further reasoned that for clients with positive abnormal fees, the benefits to the auditor from acquiescing to client pressure for opportunistic earnings management can outweigh the associated costs (e.g., increased litigation risk, loss of reputation). For those firm's earnings increase has been gained through doubtable accounting practices are likely to pay higher audit fee to persuade its auditors to certify for those earnings and give it a better audit opinion than the facts merit (Xie et al. 2010). As a possible explanation for the relationship between audit fees and earning management in banks, Lobo et al. (2010) suggested firms that are more difficult to audit have higher incentives to manage earnings, and auditors are likely to charge higher audit fees to firms that are more difficult to audit, this will be expressed in a positive relationship between audit fees and abnormal LLP. Therefore in this study a positive relationship between audit fees (abnormal) and earning management (measured through abnormal LLP) is expected.

H8: Banks abnormal accruals has positive relationship with abnormal high audit fees 
Audit Fee Determinants and Audit Quality

\section{Model and variable description}

In order to test the research hypothesis discussed in the earlier section, three testable models are developed. The first model is used to estimate audit fee. The other two models are employed to test the hypothesis developed for auditor independence and audit quality.

In order to examine the auditor independence, the study examines the two theoretical constructs i.e. the economic bond to the audit client and earnings management by the client. The study identifies proxies to measure the economic bond and earnings management because these two constructs are unobservable. Kinney and Libby (2002) cited in Choi et al. (2010) reason that the economic bond is likely to strengthen as unexpected non-audit and audit fees increase because the abnormal rents earned by the auditor increase. This study used abnormal fees as measure of the economic bond and the abnormal component of a bank's LLP as the measure of earnings management. As Lobo et al. (2010) suggested banking firms provide a setting with a stronger link between earning management and abnormal loan loss provision than that characterizing prior research. Therefore, the study examines the relation between the fee measures and abnormal LLP to draw inferences about the unobserved link i.e. economic bond and earning management. To do so, this study used a two stage procedure. First, the study estimates the normal component of audit fees and LLP. Then the residuals from the respective models are used in the audit quality model to see the link between abnormal audit fees and abnormal LLP.

\subsection{Audit fee model}

In this model, audit fee is regressed by various factors peculiar to the banking industry and other factors that are usually found to influence the variation in audit fees in industrial companies as well. The audit fee model used in this paper was initially developed by (Fields et al. 2004) and extended by others (Ettredge et al 2011, Lobo et al. 2010) in bank audit fee studies. This study used (Fields et al. 2004) variables with some modifications to match the panel nature of the data.

$$
\begin{aligned}
& \text { LOGFEE }_{i t}=\alpha i+\beta_{1} \text {LOGASSET }_{i t}+\beta_{2} \mathrm{LQ}_{i t}+\beta_{3} \mathrm{TRANSACT}_{i t}+\beta_{4} \mathrm{EFFI}_{i t}+\beta_{5} \mathrm{ROA}_{i t} \\
& +\beta_{6} \mathrm{LGR}_{i t}+\beta_{7} \mathrm{NPLR}_{i t}+\beta_{8} \mathrm{CHOFFR}_{i t}+\beta_{9} \mathrm{CAR}_{i t}+\beta_{10} \mathrm{COMMLN}_{i t}+\beta_{11} \mathrm{BIG}_{i t}+ \\
& \text { ê.............................eq. } 1
\end{aligned}
$$

Where: LOGFEE- is the dependent variable in natural logarithm of the audit fee;

LOGASST- is the natural logarithm of total assets;

LQ_ liquid asset divided by total assets of banks

EJBE Vol. 5 No. 2/2015 
Audit Fee Determinants and Audit Quality

TRANSACCT: Demand deposits divided by total deposits;

EFFICIENCY: total operating expenses (both interest and non-interest expense) divided by total revenues (measured as net interest income plus noninterest income);

ROA: banks net income divided by average assets;

LGR: banks loan growth rate;

NPLR: non-performing loans divided by total loans;

CHGOFF: net loan charge-offs divided by loan loss allowance;

CAR: risk-adjusted capital adequacy ratio;

COMMLN: banks commercial loans

BIG: dummy variable 1 if the bank is audited by Grade A auditor, 0 otherwise; $i$ and $t$ represent individual cross-sectional unit and time respectively;

ê: error term.

\subsection{Estimation of abnormal loan loss provisions}

In order to examine the link between abnormal audit fees and abnormal loan loss provision, the normal (nondiscretionary) component of LLP should be decomposed from the abnormal (discretionary) component of LLP. Similar to (Beatty et al. 2002; Lobo et al. 2010; Obsa and Tilahun 2012) the study used a two stage procedure to disentangle the two components of LLP.

First, the normal or nondiscretionary component of LLP is estimated by regressing LLP on beginning loan loss allowance (BEGLLA), beginning nonperforming loans (BEGNPL), change in non-performing loans (CHNPL), net loan charge-offs (CHOFF), change in total loans (CHLOAN), total loans (LOANS) and dummy variable for bank owner ship (PRIVATE). Year controls are also included to control for the period effect for the fact that the various directives issued by NBE in different periods throughout the study period may affect the amount of lending and hence the Loan loss provision. Specifically, the researcher estimated the following model:

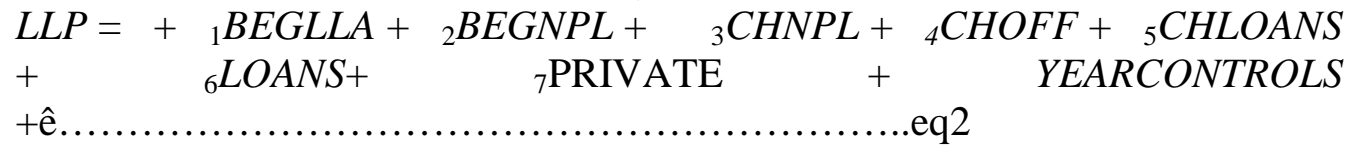

The fitted values from this model are considered as normal and the residuals are taken as the abnormal component of LLP for further analysis in the third model.

\subsection{Audit quality model}

This model is used to examine the link between the extent of earning management(through ABLLP) and the abnormal audit fees controlling for other factors which are believed to affect the level of earning management in

EJBE Vol. 5 No. 2/2015

Page 172 
prior studies (Choi et al. 2010; Lobo et al. 2011). The study controls for the effect of bank size, leverage, current performance, change in revenue, past level of accruals and auditor type. Previous research shows that large firms tend to have more stable and predictable operations and hence report a lower level of discretionary accruals than small firms. Therefore, LOGASSET is included in the model to control for the size effect. Discretionary accruals are positively correlated with firm performance, therefore the study include EBTP and change in total revenue (CHREV) to account for this effect. Further, the study also control for the reversal of accruals over time by including lagged LLP, and for capital management incentives by including capital to total asset ratio(CATA).

ABLLP $=\alpha \quad+\beta_{1}$ LOGFEE $+\quad \beta_{2}$ ABFEE $+\quad \beta_{3}$ POSABFEE + $\beta_{4}$ POSABFEE*ABFEE $+\beta_{5}$ LOGASSET $+\beta_{6}$ CATA $+\beta_{7}$ EBTP $+\beta_{8}$ CHREV $+\beta_{9}$ PLLP+ $\beta_{10} B I G+{ }_{\hat{e}} \ldots \ldots \ldots . . . e q 3$

Where: ABLLP: dependent variable abnormal loan loss provision taken from the LLP model residuals;

ABFEE: abnormal fee, the residuals from the audit fee model;

POSABFEE: positive abnormal audit fees i.e. abnormal fee taking positive sign from the audit fee model residuals;

POSABFEE*ABFEEF: interaction term for positive abnormal audit fees and abnormal audit fees

LOGASSET: Natural logarithm of total assets

CATA: banks capital total asset at the beginning of the year

EBTP: Earning before taxes and loan loss provision

CHREV: change in total revenue of banks

PLLP: lagged Loan Loss provision divided by beginning total asset.

BIG: dummy variable taking 1 if the bank is audited by Grade A auditor

ê: error term

\section{Data and sample}

The sample for the study is composed of eight commercial banks (i.e. 6 private and 2 state owned banks). In this study only secondary data is utilized. The structured review of documents enables this study to critically investigate bank audit fees determinants and audit quality than the primary data sources would allow given the confidentiality nature of the data, biased responses among the respondents and response rate considerations. A nine year audited annual report data was obtained from each of the eight banks (72 firm-year observations). In addition to financial statement, data was also obtained from NBE for items which are not reported in the bank's annual reports. One year ahead data was also used for some variables in which lagged values are 
Audit Fee Determinants and Audit Quality

required in the regression. Information regarding the auditor Grade was obtained from OFAG.

\section{Regression result for the determinants of audit fees}

Table (1) presents panel estimates for Model 1 by which banks annual audit fees are regressed by various bank level factors and auditor attributes i.e.

LOGFEE $_{i t}=\alpha_{i}+\beta_{1}$ LOGASSET $_{i t}+\beta_{2}$ LQ $_{i t}+\beta_{3}$ TRANSACT $_{i t}+\beta_{4}$ EFFI $_{i t}+$ $\beta_{5} \mathrm{ROA}_{i t}+\beta_{6} \mathrm{LGR}_{i t}+\beta_{7} \mathrm{NPLR}_{i t}+\beta_{8} \mathrm{CHOFR}_{i t}+\beta_{9} \mathrm{CAR}_{i t}+\beta_{10} \mathrm{COMMLN}_{i t}+$ $\beta_{11} \mathrm{BIG}_{i t}+\hat{\mathrm{e}}$

Table 1. Regression result for the determinants of audit fees

\begin{tabular}{|c|c|c|c|c|c|}
\hline Variable & $\begin{array}{l}\text { Expected } \\
\text { coefficient }\end{array}$ & Coefficient & Std. Error & t-Statistic & Prob. \\
\hline $\mathrm{C}$ & & -7.143929 & 4.670628 & 1.529543 & 0.1331 \\
\hline LOG(ASSET) & + & 0.66967 & 0.215246 & 3.111187 & $0.0032 * *$ \\
\hline LQ & - & -1.78712 & 0.350121 & -5.10429 & $0.0000 * *$ \\
\hline TRANSACT & + & 1.853512 & 0.884325 & 2.095962 & $0.0417 *$ \\
\hline EFFI & + & 4.211219 & 0.737829 & 5.707579 & $0.0000 * *$ \\
\hline ROAAV & + & 24.63501 & 5.791797 & 4.253431 & $0.0001 * *$ \\
\hline LGR & + & 0.59659 & 0.195921 & 3.045044 & $0.0039 * *$ \\
\hline NPLR & + & -3.132663 & 0.874188 & 3.583513 & $0.0008 * *$ \\
\hline CHFR & + & -0.033873 & 0.095681 & 0.354021 & 0.725 \\
\hline CAR & + & 1.791202 & 0.653722 & 2.740004 & $0.0088 * *$ \\
\hline BIG & + & 0.539837 & 0.091288 & 5.913531 & $0.0000 * *$ \\
\hline COMMLN & + & 0.199469 & 0.312278 & 0.638753 & 0.5262 \\
\hline
\end{tabular}

$\mathrm{R}^{2}=90.97 \%$, Adj ${ }^{2}=85.75 \%$, S.E. of regression $=0.207138$ F-statistics $=$ 17.43612 Prob (F-statistics $=0.000000)$, and Durbin-Watson stat $=1.63483$

Overall, the results reported for this model are very similar to those obtained in prior studies for other countries. First, analogous to prior studies, the model has high-explanatory power (adjusted $\mathrm{R}^{2}$ of $85.75 \%$, Table 1) and a highly significant $\mathrm{F}$ - statistics values (F-17.44). The higher explanatory power may be due to the risk and complexity variables incorporate the regulatory concerns. This suggests the model represent a fair prediction of audit fees in 
Audit Fee Determinants and Audit Quality

banking industry in Ethiopia. For instance, prior researchers in bank audit fee literature using similar models found high explanatory power of their models (e.g. field's et al.(2004), 88\%; Lobo et al.(2010),80\% and Akinpelu et al.(2013), 80\%. In addition, coefficients of most of the variables except NPLR and CHFR have the predicted sign and the majority of them attain statistical significance at the conventional 0.05 level except for CHFR and COMMLN.

As reported in Table 1, bank size, liquidity, efficiency, loan growth, profitability, non-performing loan, capital adequacy ratio and auditor size are statistically significant factors that influence the determination of audit fees in Ethiopian commercial banks. All the variables are significant at $1 \%$ level except transaction accounts, commercial loan and charge off rates. While transaction account attains significance at 5\% level, commercial loan and charge off rates remain insignificant at any conventional level. It is also worth noting that contrary to the expected positive coefficient sign, non-performing loan and charge off rates reported negative sign.

\section{Results for Banks earning management}

As previously discussed, in order to decompose the abnormal component of loan loss provision from the normal, the researcher regressed loan loss provision on factors normally considered influencing it in Model 2. The Estimation results for this model are presented in Table 2 below.

$L L P=\alpha+\beta_{1} B L L A+\beta_{2} B N P L+\alpha \beta_{3} C H N P L+\beta_{4}$ CHOFF $+\beta_{5}$ CHLOANS + $\beta_{6} L O A N S+\beta_{7}$ PRIV + YEARCONTROLS +ê

Table 2. Estimation results for abnormal Loan Loss Provision (Dependent variable LLP)

\begin{tabular}{|l|l|r|r|r|r|}
\hline Variable & $\begin{array}{l}\text { Expected } \\
\text { coefficient }\end{array}$ & \multicolumn{1}{|c|}{ Coefficient } & Std. Error & \multicolumn{1}{c|}{ t-Statistic } & \multicolumn{1}{|c|}{ Prob. } \\
\hline C & & -0.006823 & 0.00302 & -2.2573 & 0.0279 \\
\hline BLLA & - & -0.077276 & 0.07144 & -1.0817 & 0.284 \\
\hline CHNPL & + & 0.195883 & 0.04945 & 3.96163 & $0.0002^{* *}$ \\
\hline CHLOAN & $+/-$ & -0.004063 & 0.01262 & -0.3219 & 0.7487 \\
\hline CHOFF & + & 0.34219 & 0.1616 & 2.11747 & $0.0387^{*}$ \\
\hline LOAN & + & 0.015623 & 0.00679 & 2.30178 & $0.0251^{*}$ \\
\hline BNPL & + & 0.10458 & 0.04229 & 2.47313 & $0.0165^{*}$ \\
\hline PRIV & $+/-$ & -0.00247 & 0.00202 & -1.2205 & 0.2274 \\
\hline Effect specification \\
\hline Period fixed effect(period dummy variables) \\
\hline
\end{tabular}

EJBE Vol. 5 No. 2/2015 
Audit Fee Determinants and Audit Quality

$\mathrm{R}^{2}=57.80 \%, \mathrm{Adj}^{2}=46.49 \%$ S.E. of regression $=0.004228$ F-statistics $=$

5.111988 Prob(F-statistics $=0.000003)$, and Durbin-Watson stat $=1.602220$

As reported in Table 2, most of the variables attain significance at conventional levels except BLLA, PRIV and CHLOAN with their expected coefficient sign. CHNPL exhibited a positive coefficient $(0.19)$ with a highly significant at less than $1 \%$ levels ( $\mathrm{t}$ - statistic 3.96 and $\mathrm{p}$-value0.00). In addition, CHOFF, LOAN and BNPL are also statically significant at 5\% level. As expected, BLLA exhibited a negative sign suggesting that lower allowance at the beginning of the year requires a higher LLP at the end of the year and vice versa. BNPL and CHOFF have shown direct relationship with LLP implying that higher NPL and $\mathrm{CHOFF}$ at the beginning of the period require higher provision at the end of the period. This result is intuitively appealing since higher NPLR and CHOFF always requires a higher LLP. Comparatively, the model has fair explanatory power for normal (non-discretionary) component of LLP, with adjusted R-square $47.38 \%$. For example, using similar model Lobo et al. (2010) adjusted $\mathrm{R}^{2}$ was about $66.32 \%$ ).Using analogous methodObsa and Tilahun(2012) also reported unadjusted Rof 63.09 (It's obvious that the adjusted $\mathrm{R}^{2}$ could be lower though not reported).

\section{Results for the audit quality model}

For this model the residuals from model 2 were taken as an abnormal component of LLP to examine the link between abnormal audit fees and abnormal LLP. Table 3 reports the results for model 3, in which ABLLP is regressed on fee measures controlling for various factors i.e.

$\mathrm{ABLLP}=\alpha+\beta_{1}$ LOGFEE $+\beta_{2} \mathrm{ABFEE}+\beta_{3} \mathrm{POSABFEE}+$ $\beta_{4} \mathrm{POSABFEE} * \mathrm{ABFEE}+\beta_{5} \mathrm{LOGASSET}+\beta_{6} \mathrm{CATA}+\beta_{7} \mathrm{EBTP}+\beta_{8} \mathrm{CHREV}+\beta_{9}$ $\mathrm{PLLP}+\beta_{10} \mathrm{BIG}+\hat{\mathrm{e}}$ 
Audit Fee Determinants and Audit Quality

Table 3. Estimation result for the audit quality model (Dependent Variable ABLLP/)

\begin{tabular}{|l|l|r|r|r|r|}
\hline Variable & $\begin{array}{c}\text { Expected } \\
\text { coefficient }\end{array}$ & Coefficient & Std. Error & t-Statistic & \multicolumn{1}{l|}{ Prob. } \\
\hline C & & 0.02065 & 0.00815 & 2.53282 & 0.0139 \\
\hline LOG(FEE) & + & 0.00156 & 0.00091 & 1.71206 & $0.092^{*}$ \\
\hline ABFEE & + & -0.0045 & 0.00442 & -1.0234 & 0.3102 \\
\hline POSABFEE & + & 0.00063 & 0.0009 & 0.69863 & 0.4874 \\
\hline ABFEE*POSABFEE & + & 0.00266 & 0.00595 & 0.44757 & 0.6561 \\
\hline LOG(ASSET) & - & -0.0015 & 0.00047 & -3.2332 & $0.002^{* * *}$ \\
\hline CATA & - & -0.0364 & 0.01048 & -3.477 & $0.0009^{* * *}$ \\
\hline EBTP & + & 0.06946 & 0.02942 & 2.36101 & $0.0214^{* *}$ \\
\hline REVCH & - & -0.0062 & 0.00193 & -3.1902 & $0.0022^{* * *}$ \\
\hline PLLP & - & -0.0072 & 0.03757 & -0.1928 & 0.8478 \\
\hline BIG & - & -0.0002 & 0.00078 & -0.2308 & 0.8183 \\
\hline
\end{tabular}

$\mathrm{R}^{2}=27.54 \%, \mathrm{Adj}^{2}=15.66 \%$, S.E. of regression $=0.002107$, F-statistic

2.318852 Prob(F-statistic) 0.021891, and Durbin-Watson stat 2.112505

The Model fairly predicts the abnormal component of LLP in absolute value with an adjusted R-square 15.66\%, with significant F-stat. Using similar method, Choi et al. (2010) reported adjusted R-square ranging between $14.8 \%$ and $22.6 \%$ for various alternative measures of discretionary accruals.As reported in (Table 3), about six of explanatory variables including our variable interest (LOGFEE, ABFEE, POSS-ABFEE andABFEE*POSS-ABFEE) are not significant at any conventional level. However, as expected the control variables report interesting result. LOGASSET, CATA and REVCH are significant at $1 \%$ level. The negative coefficient in LOGASSET and CATA, suggest that large banks and banks with higher capitalization ratio do not seem to engage in earning management. The result confirms that earning management is directly related to the current operating performance of the bank proxied by earning before tax and provision (EBTP), while the negative sign for past level of accruals (PLLP) substantiate the negative relationship with earning management.

\section{Discussion of results for determinants of audit fee}

EJBE Vol. 5 No. $2 / 2015$ 
Audit Fee Determinants and Audit Quality

Bank Size: In line with prior studies (both industrial and financial firms), the size of the bank is highly significant at less than $1 \%$ level (p-value 0.003 ) with (coefficient 0.67 ) and t-static 3.11). The significant size coefficient can be interpreted as a $1 \%$ change in the bank's total asset accompanied by $66.97 \%$ increase in audit fees. This result is consistent with various prior empirical studies recurring finding of a positive relationship between the firm size and audit fees, both in financial and non-financial sectors. For example, (Simunic 1980; O'Keefe et al. 1994; Gonthier-Besacier and Schatt, 2007; Caneghem, 2010) find significant positive relationship between firm size and audit fees in non-financial sectors. This size effect reasoned to affect audit fees through various attributes related to complexities and risk associated with large size firms. Bank audit literature demonstrates the same effect of bank size. Cullen et al. (2012) reported the client size by itself explains over $70 \%$ variances in audit fees. It is also argued that Bank's size reflects its effect on fees through direct and indirect way, since various bank characteristics are correlated with size. Generally, the positive and significant relationship between size and audit fees in the result leads to failure to reject the first proposed hypothesis.

Liquidity risk: With regard to the liquidity proxies, LQ (liquid assets to total assets) is statistically significant at less than $1 \%$ level (p-value 0.000) with negative coefficient (-1.79 and t- static -5.10). This result indicates holding other things constant; a 1 percent increase in LQ results in $1.79 \%$ decrease in audit fees. This negative coefficient for LQ is in line with (Fields et al 2004) result for liquidity measure (securities/ total assets) indicating that banks with higher level of liquid assets relative to their total assets pay lower audit fees. As (Fields et al 2004) suggested this may be due to the fact that liquid asset portion of the bank's portfolio contains assets which are easy to value (e.g. Treasury bills, repos) and therefore, have lower audit risk and complexity.

As predicted, the other measure of liquidity risk TRANSACT (Demand deposit/Total deposits) is also significant at $5 \%$ (p-value 0.04 and t-statistic 2.09) with positive coefficient (1.85). This implies auditors tend to charge more fees for banks maintaining high proportion of demand deposits relative to their total deposits. Intuitively such relationship is expected since demand accounts are usually associated with high transaction costs, complexity and liquidity risk (Fields et al 2004). This variable also shows the banks funding structure i.e. banks which excessively rely on demand deposit are likely to suffer from liquidity problem in contrast to others. However, which particular audit fee driver (risk/complexity) is responsible for the associated higher audit fee is not clear. Fields et al. (2004) argued higher audit fees for banks with higher transaction accounts is attributable to both risk and complexity which arise out of maintaining higher level of such accounts. In contrast, Ettredge et 
al. (2011) contended increase in fees with the level of these accounts is only driven by the complexities involved with these accounts.

Efficiency risk: Similar to prior studies, for operating risk proxy EFI (defined as Total revenue/ Total expenses), the result shows statistically significant positive relationship with audit fees at less than $1 \%$ level (p-value 0.00 ) with (coefficient 4.21 and t-static 5.71). It's worth noting that since EFICIENCY ratio is an inverse measure of banks operating efficiency, the higher the efficiency ratio entails the lower the efficiency for the banks and the more difficult it is for banks to earn profit and thus to bolster their capital account. Management deficiency can attract fraud and errors in management and operations leading to higher audit risk and the associated fee (Ettredge et al. 2011).Gaganis and Pasiouras (2007) reported inefficiency as one of the reason for auditors to issue qualified audit opinion in Asian banks. This result is consistent with(Fields et al 2004, Schneider and Tran 2013 and Ettredge et al. 2011) who found positive relationship between audit fees and efficiency.

Profitability: This study used only ROA as a proxy for profitability, for the fact that the sampled banks have not experienced loss during the studied period. The result shows a significant positive relationship between ROA and audit fees at less than $1 \%$ level (P-value 0.00) with (coefficient 24.63and tstatic 4.25). This finding is in line with (Joshi and AL-Bastaki (2000) cited in Naser, et al. 2007) argument that companies with a higher level of profit are subject to a further inspection of the related revenue and expense accounts leading to raise audit effort/time on the auditor part and hence the auditor charges a higher audit fee to a more profitable banks.

Credit risk:With regard to the credit risk measures, both asset quality proxies (non-performing loan rates and Net-loan charge offs) turn out to be contrary to the expected coefficient sign. But only NPLR attain significance at $1 \%$ level while CHFR remain insignificant. This result is not consistent with (Fields et al. 2004) result that report positive and significant relationship between both asset quality measures and audit fees.

The credit risk proxy attributable to the loan portfolio composition differences, commercial loan (COMML) exhibit positive coefficient as expected but failed to gain significance at conventional level. The credit risk proxies don't seem to influence audit fees and even found to be contrary to the expected positive sign in case of NPL. This can be viewed as evidence for the fact that auditors do not tend to put much emphasis on the asset quality when pricing their audit services. Perhaps this may be due to fact that NPLS have been declining continuously throughout the studied period on banks level as well as yearly averages of the sampled banks. 
Capital risk: The estimated coefficient for capital risk proxy risk weighted Capital adequacy ratio (CAR) exhibited positive and statistically significant at $1 \%$ level (0.008) with (coefficient 1.79and t-statistic 2.74). Theoretically, the relationship between audit fees and capital risk should be negative. However, as suggested by (Fields et al. 2004) the relationship between audit fees and the risk-adjusted capital ratio could conceivably be positive or negative noting that riskier banks are often required by regulators to maintain larger regulatory capital cushions. In our case NBE sets the minimum CAR $8 \%$ and the sample banks average CAR is about $16 \%$ for the studied period, signifying that they have ratios well above the minimum requirement.

Auditor size: Finally, the estimated coefficient for auditor size (BIG) showed positive sign and statistically significant at $1 \%$ level $(0.00)$. This suggests Grade "A" auditors charge higher audit fees than the others. This result is also consistent with "big auditor's premium hypothesis" which conjectured large audit firms provide a higher quality audit and charge higher audit fees for their service. The result is similar with various previous researches who reported fee premium for large auditors, (e.g. Palmrose1986; Francis and Simon 1987; Fields et al. 2004).

\section{Discussion of results for audit quality}

The coefficients of interest in the audit quality model are only log fee, ABFEE AND POSS-ABFEE for the fact that the purpose is only to see the link between economic bond and earning management. As reported in Table 3, only $\log$ fee is significant at $10 \%$ with positive coefficient while the other variables of interest in the regression didn't gain statistical significance at conventional level. Even though, the significance of logfee suggest auditors compromise audit quality for banks paying higher audit fees, it is usually argued that audit fees doesn't capture the economic bond or likely to raise nontrivial measurement error (Choi et al. 2010). Further, auditors may charge higher audit fees for companies which are likely to manage earning because of the risk involved with such clients.

Although statistically insignificant, ABFEE exhibited negative coefficient suggesting that ABFEE decrease when ABLLP are higher in absolute value. This result is totally paradoxical with the proposed hypothesis. It also contradicts with the result reported for the relation between audit fees and absolute value of discretionary accruals. However, it is important to note that ABFEE is composed of both positive and negative components and auditor independence is only likely to be impaired if a significant positive relationship exist between ABFEE and ABLLP (Choi et al. 2010). To account for this, the interaction term POSS-ABFEE* ABFEE is introduced in the regression. Even 
though, the coefficient takes a positive sign in this case, it is statistically insignificant. This result can be interpreted in alternative ways in relation to the auditor's independence and the audit quality. First, with regard to auditor's independence, given intense competition in the audit market coupled with the regulatory scrutiny may possibly make it difficult for auditors to charge abnormally higher audit fees that could threaten their independence. Further, it can be intuitively argued taking in to account the lower level of fees rates and the competitive forces auditors in fact may prefer to extend their tenure and reap normal fees from their continuing relationship. In general, the result suggests auditors do not seem to compromise their independence for the sake of securing abnormally high audit fees as long as the measure of earning management employed in this paper is concerned.

Secondly, the maintenance of auditor independence doesn't always imply good audit quality. In addition to the auditor independence auditor technical capabilities and expertise, level of extensive tests and the presence of audit quality reviews also determine the quality of the audit. The positive relationship of the absolute value of ABLLP with EBTP and CHREV indicates that banks in deed manage earning for income smoothing purpose. But this is not related to auditor's impairment in any way. In fact, the lower fee level partly due to the stiff competition in the country may be considered as a reason for auditors not to plan and conduct an extensive standard quality audit that could possibly enable them to reveal such opportunistic behavior.

\section{Conclusion and Recommendations}

This study assesses audit fee determinant factors in the Ethiopian banking industry. The study also examined whether abnormal audit fees influence auditor independence and audit quality by using abnormal component of LLP as proxy for earning management (i.e. audit quality measure). In general, the analysis revealed, Ethiopian audit firms tend to value size of the bank, operating efficiency, liquidity, capital adequacy, auditor size and profitability in the determination of bank audit fees. Among the variables considered important by regulators (i.e. CAMEL ratios), only asset quality/ credit risk found to be insignificant. The insignificancy of the credit risk may be due to its highly competitive market set up and the presence of vigilant regulatory body. Given high level of competition, auditors may find it difficult to consider every aspect of the regulatory concern. As Boo and Sharma (2008) suggested regulatory oversight partially substitutes the external audit as a monitoring mechanism and influences the extent of auditing provided by the external auditor.

EJBE Vol. 5 No. 2/2015 
With regard to audit quality, the result did not show any auditor independence impairment for the sake of securing higher audits fees. In fact, the result suggests banks seem to engage in earning management activities. But, auditors do not collaborate with banks to manage earning as far as the economic bond measure adopted in this study is concerned. This may be due to moral hazard problem that leads auditors to plan less intensive audit. Further, the lower audit fee level may not also allow auditors to conduct intensive audits.

Since the banking sector, is characteristically different by the presence of vigilant regulatory oversight, it is recommendable to consider factors which are important to the regulatory bank. In fact, this study found that auditors do consider some of these regulatory concerns but it still remains with regard to some of these important factors. The banking sector internationally lessened a lot as to how credit risk could potentially threaten their survival/ going concern. Further, Ethiopian commercial banks significantly increased their offbalance sheet activities by devoting a large sum of money which potentially increases the banks risk exposure by threatening their capital adequacy ratio. Therefore, the researcher recommends auditors to take into to account banks asset quality/ credit risk, which are important to regulators, in their determination of audit fees. The better alignment of the regulatory interest would help auditors in terms of avoiding costly litigation associated with audit failure.

The study found that Ethiopian banks seem to actually engage in earning management activities but auditors failed to inspect such practices. To curb such opportunistic behavior of banks the researcher recommends auditors to conduct intensive audit. Further the researcher recommends regulators such as NBE to reconsider how the audit fees for banks should be determined. Lower fee by itself would not allow auditors to conduct good quality audit. Therefore, lower fee levels triggered by the stiff competition in the audit market are likely to end up with lower quality standard audits.

\section{Limitations and Future Research}

This study tried to investigate audit fee determinant factors and the ex-ante audit quality in the Ethiopian banking industry. However, the results of the study may suffer from some limitations. First, the model adopted in this study is developed in the context of developed countries though, efforts have been made to contextualize in the country context; it may not well explain Ethiopian audit practice. Second, for the reason that some items are not consistently reported in the financial statement of all banks the study used calculations to best proxy those items (for example, capital adequacy ratio and loan charge offs). This may induce some biases on the reported result. Third, since the 
measure used for earning management Abnormal Loan Loss Provision (ABLLP) and economic bond (Abnormal Audit Fees) is taken as the residuals from their base models in which its accuracy relies on the specification of the underlying models, thus the result may be biased probably for uncontrolled methodological issues. Lastly, the study failed to provide additional sensitivity analysis due to the lower sample size to undertake such a test. Therefore the researcher recommends future researchers to employ a larger sample size from both the financial and non-financial industries. The researcher also recommends future researchers to study the audit fee structure, audit quality and independence issues with different methodologies (qualitative or Mixed), so that they can circumvent the limitation of the model that the researcher adopted in this study. 
Audit Fee Determinants and Audit Quality

\section{References}

Ahmad A.C., Shafie, R. and Mohamad Y. N. 2006, 'The provision of non-audit services, audit fees and auditor independence', Asian academy of management journal of accounting andfinance, Vol. 2, No. 1, 21-40.

Akinpelu, Y. A. O., Omojola, S.O., Ogunseye, T. O. and Bada O. T. 2013. "The Pricing of Audit Services in Nigeria Commercial Banks" Research Journal of Finance and Accounting ISSN 2222-2847, Vol.4, No.3.

Al-Harshani, M.O. 2008, 'The pricing of audit services: Evidence from Kuwait', Managerial Auditing Journal, Vol. 23 Iss: 7 pp. 685 - 696.

Anandarajan, A., Hasan. I., and McCarthy, C. 2005.'The Use of Loan Loss Provisions for Earnings, Capital Management and Signaling by Australian Banks."

Balla E., Rose, M.J., and Romero J. 2012. "Loan Loss Reserve Accounting and Bank Behavior", Economic Brief, EB12-03 - The Federal Reserve Bank of Richmond."

Beattie, V. 2012. Initial review of relevant academic literature, Competition Commission Statutory Audit Market investigation.

Beatty, A.L., Ke, B., and Petroni, K. R. 2002. "Earnings management to avoid earnings declines across pubicily and privately held banks" The Accounting Review Vol. 77. No. 3, pp. 547-570.

Boo, E., and Sharma D. (2008). "Effect of regulatory oversight on the association between internal governance characteristics and audit fees that auditors perceive lower risk" Accounting and Finance 48 (2008) 51-71.

Boo, E., and Sharma D. 2008. "The association between corporate governance and audit fees of bank holding companies" Corporate Governance VOL. 8 No. 1, pp. 28-45.

Caneghem, T.V. 2010, "Audit pricing and the Big4 fee premium: evidence from Belgium", Managerial Auditing Journal, Vol. 25, Iss: 2 pp. 122 139.

Choi, J., Kim, J and Zang, Y 2010. 'Do Abnormally HighAudit Fees Impair Audit Quality?'Auditing: A Journal of Practice \&Theory, American Accounting Association, Vol. 29, No. 2, pp. 115-140.

Curcio, D and Hasan, I. 2008. "Earnings- and Capital-Management and Signaling: The Use of Loan-Loss Provisions by European Banks",

Dart, E. 2009. 'UK Investors' Perceptions of Auditor Independence' Working Papers in Accounting and Finance ISSN 1750-6638.

Davis, L, R., Ricchiute, D.N, and Trompeter, G. 1993 'Audit Effort, Audit Fees, and the Provision of Non audit Services to Audit Clients' The Accounting Review, Vol. 68, No. 1, pp. 135-150.

DeAngelo, L.E., 1981, 'Auditor size and audit quality', Journal of Accounting

EJBE Vol. 5 No. 2/2015 
and Economics, Vol. 3, pp. 183-199.

Defond, M.L., Raghunandan, K. and Subramanyam, K. R. 2002. 'Do Non -Audit Service Fees ImpairAuditor Independence? Evidencefrom Going Concern AuditOpinions', Journal of Accounting Research, Vol. 40, No. 4.

Deloitte 2012.Banking regulatory environment and supervision in Africa, Deloitte on Africa Collection: Special Edition.

Doogar, R.S. and Sivadasan, P. 2012. Asleep at the wheel again? Bank audits during the financial crisis. Working Paper.University of Illinois at Urbana -Charnpaign.

Ebrahim, A., 2010. 'Audit fee premium and auditor change: the effect of Sarbanes-Oxley Act", Managerial Auditing Journal, Vol. 25 Iss: 2 pp. 102 $-121$.

El-Gammal, W. 2012, 'Determinants of Audit Fees: Evidence from Lebanon', International Business Research, Vol. 5, No. 11, ISSN 1913-9004 E-ISSN 1913-9012.

Ettredge, M., Xu, Y. and Yi, H. 2011. "Fair Value Measurements and Audit Fees: Evidence from the Banking Industry". Working paper, The University of Kansas - School of Business and KoreaUniversity Business School.

Fields, L.P., Fraser, D.R., and Wilkins, M.S. 2004. "An investigation of the pricing of audit services for financial institutions" Journal of Accounting and Public Policy 23, 53-77.

Francis, J.R. and Simon, D.T. 1987, 'A Test of Audit Pricing in the Small -Client Segment of the U. S. Audit Market', The Accounting Review, Vol. 62, No. 1, pp. 145-157.

Gaganis, C. and Pasiouras, F. 2007 "A multivariate analysis of the determinants of auditors' opinions on Asian banks" Managerial Auditing Journal Vol. 22 No. 3, pp. 268-287.

Gonthier-Besacier, N. and Schatt, A. 2007, 'Determinants of audit fees for French quoted firms', Managerial Auditing Journal, Vol. 22 Iss: 2 pp. 139 $-160$.

Ireland, J.C. and Lennox, C.S. 2002, 'The large audit fee premium: a case of selectivity bias?',Journal of Accounting, Auditing and Finance, Vol. 17 No. 1, pp. 73-91.

Kanagaretnam, K., Krishnan, G.V., and Lobo, G.J. 2010."An Empirical Analysis of Auditor Independence in the Banking Industry" The Accounting Review Vol. 85, No. 6 pp. 2011-2046.

Mihret, D.G. 2011, 'Reliance of External Auditors on Internal Audit Work: A Corporate Governance Perspective', International Business Research, Vol. 4, No. 2, pp. 67-79. 
Audit Fee Determinants and Audit Quality

Naser, K., Abdullhameed H. and Nuseibeh, R. (2007), 'Determinants of audit fees from emerging economy', scientific journal of administrative and development vol. 5, pp. 84-116.

Obsa T. and TilahunA. 2012. 'The Impact Of Corporate Governance Mechanisms On Earnings Management: Evidence from Banks in Ethiopia', International Journal of Research in Commerce, Economics \& Management Volume No. 2, ISSUE NO.8, ISSN 2231-4245.

Office of the Federal Auditor General 2009, Ethiopian Code of Ethics for Professional Accountants.

O’Keefe, T.B., Simunic, D.A. and Stein, M.T. 1994, 'The Production of Audit Services: Evidence from a Major Public Accounting Firm'. Journal of Accounting Research, Vol. 32, No. 2, pp. 241-261.

Palmrose, Z. 1986, 'Audit Fees and Auditor Size: Further Evidence' Journal of Accounting Research, Vol. 24, No. 1 pp. 97-110.

Pérez, D, Salas, V and Saurina J. 2006. "Earnings and Capital Management In Alternative Loan Loss Provision Regulatory Regimes" Banco De EspañaDocumentos de Trabajo No. 0614, ISSN: 1579-8666 (on line)

Schneider, F and Tran, D.H. 2013 "The Role of Fair Values in the Pricing of Audit Services - Evidence from European Banks".

Simunic, D.A. 1980, 'The Pricing of Audit Services: Theory and Evidence', Journal of Accounting Research, Vol. 18, No. 1, pp. 161-190.

Thinggaard, F. and Kiertzner, L. 2008, 'Determinants of Audit Fees: Evidence from a Small Capital Market with a Joint Audit Requirement', International Journal of Auditing Vol. 12. Pp. 141-158.

Walter, J. R., 1991 "Loan Loss Reserves", Economic Review, American Banker various 1991 issues

World Bank 2007, Report on the observance of standards and codes (ROSC) Ethiopia

Xie, Z., Cai, C., and Ye, J. 2010. 'Abnormal Audit Fees and Audit OpinionFurther Evidence from China's Capital Market', China Journal of Accounting Research, Vol 3 Issue 1, PP. 51-70.

Zhang,Y., Monroe, G., Gasbarro, D., Cullen, G., Shailer.G. "Asset Securitizations and Audit Effort"

EJBE Vol. 5 No. 2/2015 